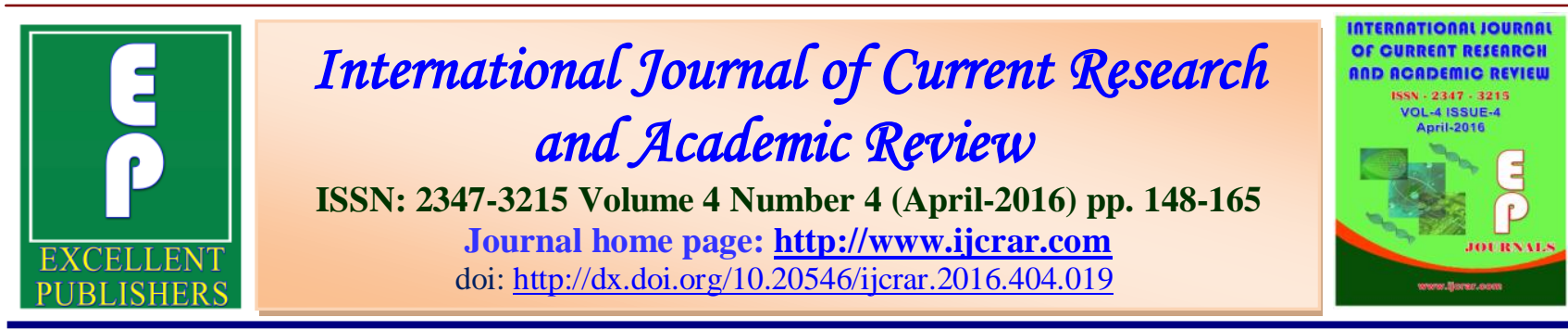

\title{
Effect of Pretreatments and Storage Conditions on Shelf life Extension of Sapota (Achras zapota) Fruit and on Quality of Osmo-Dehydrated Slices
}

\author{
K. Amarjeet ${ }^{1}$, A. S. Chauhan ${ }^{1 *}$, K. Srinivasulu ${ }^{2}$, R. Ravi $^{3}$ and V. B. Kudachikar ${ }^{1}$ \\ ${ }^{1}$ Department of Fruit and Vegetable Technology, CSIR-Central Food Technological Research \\ Institute, Mysore-570 020, India \\ ${ }^{2}$ CSIR-CFTRI-Resource Centre, Hyderabad, India \\ ${ }^{3}$ Traditional food and Sensory Science Department, CSIR-Central Food Technological \\ Research Institute, Mysore-570 020, India \\ *Corresponding author
}

\section{KEYWORDS}

Calcium salt, low temperature, Keeping quality, Dehydrated sapota slices,

Shelf

Stability.

\section{A B S T R A C T}

The aim of the present study pertains to the extension of shelf life of fresh sapota pretreated with varying concentrations of calcium chloride at low temperature (LT) storage and thereafter to appraise stored sapota for the development of osmodehydrated slices using hypertonic sugar syrup. In the present study, an attempt was made to prolong the shelf life of Sapota fruits by maintain the initial fruit quality attributes under the influence of surface coatings with fruit hardening chemical agent and low temperature (LT) storage condition and to find out its suitability for processed product development. Optimally matured (13.30Brix) Sapota (var.Cricket ball) fruits pretreated with solutions of calcium chloride at various levels (3.0, 4.0 and $4.5 \%)$ and were stored at $\mathrm{LT}\left(12 \pm 1^{\circ} \mathrm{C}, 90-95 \% \mathrm{RH}\right)$ condition. Results indicated that optimally matured, LT $\left(12 \pm 1^{\circ} \mathrm{C}, 90-95 \% \mathrm{RH}\right)$ stored sapota fruits, pretreated with Calcium chloride treatments $\left(\mathrm{T}_{2}-4 \%\right.$ Calcium chloride and $\mathrm{T}_{3}-4.5 \%$ Calcium chloride) were most effective surface hardening chemical agents. Only these treatments were effective with better retention of the fruit quality attributes such as, fruit texture, acidity, ascorbic acid, total soluble solids, total sugar and reducing sugars, without fruit spoilage, with effective shelf life of 32 days as compared 24 days in untreated control sapota fruits stored at same storage condition. Both the Initial and final dehydrated sapota slices prepared from these treatments $\left(\mathrm{T}_{2}-4 \%\right.$ Calcium chloride and $\mathrm{T}_{3}-4.5 \%$ Calcium chloride) were found to be excellent in terms of all the product quality parameters evaluated with the shelf stability of 4 months at RT $\left(29 \pm 2{ }^{\circ} \mathrm{C}, 60-75 \% \mathrm{RH}\right)$ condition. Moisture sorption studies of these dehydrated sapota slices revealed that flexible packaging materials such as $75 \mu \mathrm{m} \mathrm{LDPE}$ or $50 \mu \mathrm{m}$ cast PP or $25 \mu \mathrm{m}$ HDPE can give the required protection. The osmo-dehydrated sapota slices developed in this study represents an innovative and natural processed products from sapota fruits pretreated with $\mathrm{T}_{2}-4 \%$ Calcium chloride and $\mathrm{T}_{3}-4.5 \%$ Calcium chloride after effective storage life of 32 days at $\mathrm{LT}\left(12 \pm 1^{\circ} \mathrm{C}, 90-95 \% \mathrm{RH}\right)$, which can be incorporated into different food products due to its high nutritional and sensory quality attributes. 


\section{Introduction}

The tropical sapota (Achras zapota) fruit belongs to the family sapotaceae and cultivated in various states of India by the farmers. It has mild flavor, white latex inside the fruit, unique sweet taste of digestible sugar ranging from $12-20 \%$ and bestowed with mineral contents like iron and calcium (Ahmed et al., 2011). The shelf life of fresh sapota fruits is very short, the reason behind may be its inherent climacteric nature, presence of oxidative enzymes and ethylene. Due to the perishable nature of sapota fruits, it is imperative to study its post-harvest handling and storage methods for shelf life extension (Ganjyal $e t$ al., 2003; Sauri-Duch et al., 2010). In spite of the fact that fruit is known for a range of sapota processed products, such as, marmalades, jellies, juices and soft drinks (Amarjeet Kumar et al., 2016), this fruit is usually consumed in the fresh form. However, the export of fresh Sapota from producing countries has been restricted because this fruit is highly perishable, difficult to handle and transport in fresh form due to quick ripening and fruit softening. Calcium supports to sustain the shelf life of fresh vegetables and fruits as well as different calcium salts have been studied to prevent the deterioration, and maintained hygiene and nutritive extension of fresh produce.

Calcium carbonate and calcium citrate are the main calcium salts added to foods in order to advance the nutritive value (Brant, 2002). Many other calcium salts used in the food manufacturing industry are calcium chloride, calcium lactate, calcium phosphate, and calcium propionate, which are used more to improve the product firmness (Manganaris et al., 2007; Alzamora et al., 2005). Calcium chloride has been broadly used as preservative and firming agent in the fruits and vegetables industry for whole and fresh-cut merchandises (Chardonnet et al., 2003). Physiological activity of Calcium that maintained the fruit cell wall structure and act as a second messenger in cellular biochemistry for proper growth and development and also maintained the general quality of fruit (Kadir, 2004).

There has been interest in the use of various calcium salt solutions for prolonging the shelf life of fresh-cut fruits and vegetables (Luna-Guzman and Barrett, 2000; Garcia and Barrett, 2002). Postharvest treatment with $1 \%$ solution of calcium chloride delayed fruit ripening, improved resistance to fungal attack and maintained structural integrity of cell walls of strawberry during a 10 day storage period at $3^{\circ} \mathrm{C}$ (Lara et al., 2004). Furthermore, softening was delayed and storage life was increased by $10-12$ weeks in Kiwi fruits stored at $0^{\circ} \mathrm{C}$ by using of $1 \%$ calcium chloride, compared with untreated fruit (Dimitrios and Pavlina, 2005). Treatment of fresh-cut cantaloupe melon with calcium solution was effective in inhibiting lipase enzymes that catalyze membrane-bound lipids (Lamikanra and Watson, 2004). Keeping in view the usefulness of calcium chloride treatment in various fruits as reported by various researchers, the present study was pointed to evaluate the effectiveness of postharvest dip treatment of calcium chloride at different concentrations on the keeping quality and shelf life extension of sapota fruits at low temperature $\quad\left(12 \pm 1^{\circ} \mathrm{C}, 90-95 \mathrm{RH} \%\right)$ condition and their effect on osmodehydrated processed product of sapota after effective storage in fresh form.

Extending shelf life with least packaging requirements and reducing the bulk during transportation are the aims of drying of fruit and vegetable for food product preparation 
(Pua et al., 2007; Youssef et al., 2009). Dehydration food preservation method is a highly appropriate process for heat-sensitive products that results into dehydrated fruit powders with good quality, low water activity, and easier transport and storage (Tonon et al., 2009). It has been widely used in many fruits and vegetables such as guava (Chopda and Barrett, 2001), pineapple (Abadio et al., 2004), cashew apple (De Oliveira et al., 2009), pomegranate (Youssef et al., 2009), mango (Cano-Chauca et al., 2005).

Due to the enormous process variables influencing the quality of dehydrated fruit slices and in order to obtain products with better characteristics and process yield, it is important to optimize the drying process (Tonon et al., 2008). Despite a large number of studies performed on optimization of drying of fruits and vegetables, there is a lack of sufficient knowledge on the development of dehydrated sapota fruit slices obtained from the calcium salts pretreated, low temperature stored sapota after extended shelf life and postharvest quality maintenance.

Therefore, the main objectives of this work was to evaluate the effect of fruit hardening pretreatments with calcium salt at various levels and the storage condition on shelf life and postharvest quality of sapota (Achras zapota) in fresh form and to develop osmodehydrated slices from calcium salts pretreated sapota fruits after effective shelf life of 24 days at low temperature, by using the appropriate drying technique and to evaluate their physicochemical, and sensory properties as well as their stability under different humidity conditions, for suitability of packaging films and for shelf life predictions. The long-term purpose of this work is to develop dehydrated sapota fruit slices packed in suitable packaging film to achieve higher shelf stability of this product.

\section{Material and Methods}

\section{Selection of Raw Material}

Fresh, firm and optimally matured $\left(13.3^{\circ}\right.$ Brix, soluble solids content) sapota (Achras zapota) variety 'Cricket ball 'fruits were harvested from a commercial sapota orchard near Mysore, India. Sorted, graded for uniform size and color in order to obtain uniform fruits according to its ripening grade $\left(13-14^{\circ}\right.$ Brix and $80 \%$ of skin yellowness), shape and size. Fruits were loaded into flexible plastic crates (FPC) with proper cushioning with paper strips at the base and transported to CFTRI, Mysore, India, and were precooled in the pre-cooling chamber at $12 \pm 10^{\circ} \mathrm{C}, 90-95 \% \mathrm{RH}$ for 18 hours to reduce field heat and to reduce the fruit metabolic activity. Fruit hardening chemical reagents calcium chloride procured from Mark chemicals.

\section{Storage Studies of Fresh Sapota under Various Post-Harvest Treatments}

After precooling fruits were stored and graded for uniform size, colour and firmness and grouped into various lots for postharvest dip treatments. Aqueous solutions of calcium chloride 3\%, $4 \%$ and $4.5 \%$ were prepared in potable water. Sapota fruits were dipped in each solution for 15 minutes and surface air dried in shade and stored at Low temperature $\quad\left(12 \pm 1^{\circ} \mathrm{C}, \quad 90-95 \% \quad \mathrm{RH}\right)$ condition. The stored fruits were periodically analyzed for changes in various physico-chemical and other quality characteristics in triplicates and the average values for each quality parameters are presented. 
Processed product (Osmo-Dehydrated) development from fully ripe sapota fruits after LT storage

The flow chart for the preparation of osmodried sapota slices is illustrated in Figure 1. After effective storage life (of 32 and 24 days in pretreated and control respectively) of sapota fruits stored at low temperature $\left(12 \pm 1^{\circ} \mathrm{C}\right)$, becomes soft, turned color to dark brownish yellow and were allowed to attain complete ripe stage at $\mathrm{RT}\left(27 \pm 1^{\circ} \mathrm{C}\right)$ for 3 days. Before processing, the fully ripe fruits (T0-Control; $\mathrm{T}_{1}-3 \%$ Calcium chloride; $\mathrm{T}_{2}-4$ $\%$ Calcium chloride; $4.5 \%$ Calcium chloride) were sorted and graded for uniform size, color, and firmness. Water washing of selected sapota fruits, fully ripens sapota fruits were cut in slices of equal size, dipped into sodium hypochlorite $(0.05 \%)$ solution to achieve an acceptable sanitary status and then processed. The sapota slices then dipped in 50\% sugar syrup (slices to syrup ratio, 1:1) solution containing $0.25 \%$ Citric acid, $0.1 \% \mathrm{KMS}$ for 2 hours at room temperature (29 $\pm 20 \mathrm{C})$. After 2 hours, the sugar solution was drained out and the sapota slices were kept for drying in hot air oven maintained at $600 \mathrm{C}$ for 6 hours to achieve the consistent moisture content to $11-15 \%$. The storage stability studies of the sapota slices packed in polythene bags and stored at RT $\left(29 \pm 2^{\circ} \mathrm{C}\right.$ $60-75 \% \mathrm{RH})$.

\section{Storage stability studies of osmo-dried sapota slices}

The dehydrated slices from sapota fruits from all the treatments were obtained and were stored at room temperature (RT) $\left(29 \pm 2^{\circ} \mathrm{C}, 60-75 \% \mathrm{RH}\right)$ for further storage behaviour for 4 months. The product was evaluated in triplicates from each treatment for changes in the various physico-chemical and sensory quality attributes and the mean value were reported $(\mathrm{n}=3)$. The product obtained was slightly hard and may absorb moisture from air, therefore, the product was packed in LDPE bags, sealed and was stored at RT $\left(29 \pm 2{ }^{\circ} \mathrm{C} 60-75 \% \mathrm{RH}\right)$ for their storage stability and product quality evaluation studies.

\section{Moisture sorption studies}

\section{Initial Moisture Content (IMC \%)}

This was determined by drying known weight of the product taken in Petri dish at $100 \pm 5^{\circ} \mathrm{C}$ till constant weight as per the procedure (AACC, 1983). Further, moisture sorption behavior and storability studies of the dehydrated sapota slices were carried out for product quality evaluation at RT Storage $\left(27 \pm 1{ }^{\circ} \mathrm{C}\right)$ condition. Known quantity of the products were taken in petridishes and was exposed to different levels of relative humidities (RHs) ranging from 11 to $92 \%$ built in desiccators using appropriate saturated salt solutions (Lopez et al., 1995). The samples were periodically weighed till they attained constant weights or showed signs of mould growth whichever was earlier. After equilibration, the moisture content (MC) of the product at different RHs was calculated by adding/subtracting \% pick up/loss to/from the initial moisture content. The sensory remarks on their quality were taken and critical moisture content was fixed. The selection of packaging material was carried out by computing permissible moisture uptake by the product $(150 \mathrm{~g})$, the volume occupied by the water vapour, the differential water vapour pressure and the permissibility of water vapour through a film by the following expression (Rangana, 1977).

$$
\begin{gathered}
\mathrm{P}=\frac{\mathrm{q}}{------} \\
\text { At (p1-p2) }
\end{gathered}
$$


Where, Where, $\mathrm{P}$ is the water vapour transmission of the film,

$q=$ Quantity of water vapour or gas (in cc)

$\mathrm{t}=$ Time of storage (in seconds)

$\mathrm{P} 1$ - P2 = Vapour pressure differential expressed (in $\mathrm{cm}$ of $\mathrm{Hg}$ )

$\mathrm{A}=$ Effective area of package $($ in $\mathrm{Sq} \mathrm{cm})$

p1 is water vapour pressure outside the package and $\mathrm{p} 2$ is the water vapour pressure inside the package.

\section{Physicochemical Analysis}

\section{Determination of Moisture content (MC)}

Moisture content of the sample was determined by using a Digital Moisture Analyzer (Denver instruments Germany, Model-IR 35, Germany) at $110 \pm 2^{\circ} \mathrm{C}$. A sample of 2-3 $\mathrm{g}$ was exposed to the heated infra-red coils of the moisture analyzer and the analysis was completed in an automatic mode within 15-20 minutes.

\section{Fruit Texture}

Fruit texture of the sample was measured in terms of penetration test by using the Texture measuring system (LLOYD, Model LR5K) fitted with the needle probe of $8 \mathrm{~mm}$ diameter with load cell $1(\mathrm{KN})$ and cross speed of $50 \mathrm{~mm} / \mathrm{min}$. The randomly selected samples were placed at the base of the Texture measuring system (LLOYD, Model LR5K). The maximum force $(\mathrm{N})$ used was defined as firmness.

Fruit Color in terms of CIE values ( $\mathrm{L}^{*}, \mathrm{a}^{*}$, $\left.b^{*}\right)$

Fruit Colour measurement was taken out at three portions of each individual fruit using Colour measuring system (Hunter Lab, Lab
scan-XE) and expressed in terms of $\mathrm{L}^{*}, \mathrm{a}^{*}$ $\& b^{*}$ values (Hunter, 1975).

\section{Total Soluble Solids $\left({ }^{\circ}\right.$ Brix $)$}

The soluble solids content (SSC) of the homogenate sample was measured by using a digital refractometer (ATAGO-RX 5000, Japan) and was expressed in terms of ${ }^{\circ}$ Brix.

Titratable Acidity (as \% anhydrous citric acid)

Acidity of the homogenate sample was determined by the standard method (Ranganna, 1999) and is expressed in terms of $\%$ anhydrous citric acid.

Total Sugars (\%) and reducing sugar (\%) content

The reducing sugars (\%) total sugars (\%) in the homogenate samples were estimated as per the Lane and Eynon method (AOAC, 1990).

\section{Ascorbic Acid (mg/100g)}

The ascorbic acid content was determined using 2, 6 Dichlorophenol-Indophenol visual titration method (Ranganna, 1999). The dye is blue in alkaline solution and red in acidic solution was reduced by ascorbic acid.

\section{Total Tannin Content}

Total Tannin content was determined by the Colorimetric method based on the measurement of blue color formation by the reduction of phosphortungatomolybdic acid by tannin in alkaline solution (Ranganna, 1999).

\section{Sensory Analyses of osmo-dried sapota slices}

The dehydrated Sapota slices prepared from both treated and control fruits were evaluated for sensory quality and acceptance 
of the product. Quantitative Descriptive Analysis was used for analysis was comprised of $15 \mathrm{~cm}$ scale anchoring at low $(1.25 \mathrm{~cm})$ or detection threshold and high $(13.75 \mathrm{~cm})$ or the saturation threshold. The intensity of each specific descriptor was quantified on the structure scale. Suitable attributes specific to Sapota dehydrated slices were collected the preliminary session of evaluation and scorecards were prepared. The sensory properties were evaluated by a trained panel using a STD QDA scale (Stone et al., 1974).

Panelists were suitable trained and oriented towards the sensory technique and the product to be evaluated. Samples were randomly served to the panelists in white cups coded with 3 digit random numbers. The panelists were instructed to indicate their perceived intensity of the samples on the scorecard. Care was taken to avoid interference from other sources or bias. Evaluations were conducted under white fluorescent light, with the boot area maintained at temperature $22 \pm 2{ }^{\circ} \mathrm{C}$ and $50 \pm 5 \%$ RH. A suitable scorecard was developed using "Free-Choice Profiling" method selecting appropriate terminology. Samples were presented in porcelain plate coded with 3-digit random numbers, to the panelist. A glass of water was also presented to cleanse the plate in between the sample. Mean score were calculated and plotted against the attributes.

\section{Statistical Analysis of Data}

All determination experiments were conducted in Triplicate and expressed as mean \pm SD. An analysis of Variance (ANOVA) of the data was evaluated by Statistical Analysis System (SAS). Duncan's Multiple Range Test was employed to determine the statistical significance $(\mathrm{P} \leq$ 0.05) of differences between the means (SAS, 1989).

\section{Results and Discussion}

\section{Physicochemical changes during low temperature (LT) storage of pre-treated sapota fruits}

\section{Fruit textural characteristics}

The results on fruit colour values of Sapota fruit treated with various fruit hardening chemical agents (Table 1) showed that hunter colour $(\mathrm{L}$ a b $)$ values did not $(\mathrm{P}<0.05)$ differ among the treatments with storage time. The results on penetration force of Sapota fruit treated with various hardening agent (Table 1) showed that firmness reduced gradually with storage time. Among the treatments all the sapota fruits pretreated with calcium chloride $\left(\mathrm{T}_{1}-3 \%\right.$ Calcium chloride; $\mathrm{T}_{2}-4 \%$ Calcium chloride; $\mathrm{T}_{3}-4.5$ $\%$ Calcium chloride) had retained $(\mathrm{P}<0.05)$ higher fruit texture as compared to untreated control fruits during 32 days of LT storage time. Sharp decline in fruit texture in control fruits after 24 days led to the fruit softening thereby shortened the shelf life of these fruits. However, sapota fruits pre-treated with $\mathrm{T}_{1}-3 \%$ Calcium chloride and $\mathrm{T}_{3}-4.5$ $\%$ Calcium chloride were found harder in fruit texture at the end of storage. The retention of noticeable fruit texture in these calcium chloride treated fruits during storage might be due to its increased accretion in the fruit cell walls that further rushed the integrity of the fruit cell wall and middle lamella by amplified influx of calcium in the matrix by promoting the cross linking of pectin polymerase in the cell wall leading to the formation of calcium pectate (Amarjeet Kumar et al., 2016; Conway et al., 1997; Serrano et al., 2004). Thus, calcium improved the mechanical strength of the fruit cell wall and cell consistency (White and Broadly, 2003) of these calcium chloride treated sapota fruits. 
Effect on change in Titrable acidity (\%)

The results showed that (Table 2) among the treatments, initially titrable acidity was $0.77 \%$ in $\mathrm{T}_{1}-3 \%$ Calcium chloride and the least value $0.70 \%$ in the control .It was decreased gradually in all treated ones $(0.35 \%$ to $0.36 \%)$ and control fruits $(0.34 \%)$ at the end of storage.(Table 2). Titrable acidity is unswervingly related to the deliberation of total organic acids present in the fruit, which is a significant factor in maintaining the quality of fresh fruits (Ding et al., 1998).

\section{Effect on ascorbic acid content}

The results showed that (Table 2) among the treatments, $\mathrm{T}_{3}-4.5 \%$ Calcium chloride treated and control fruits were retained $(\mathrm{P}<0.05)$ the highest and the least ascorbic acid content $16.88 \mathrm{mg} / 100 \mathrm{~g}$ and 14.63 $\mathrm{mg} / 100 \mathrm{~g}$, respectively before LT storage. The content was gradually decreased with storage time in all the treated and control fruits and it was decreased $(\mathrm{P}<0.05)$ to the lowest levels of ascorbic acid content, 11.34 $\mathrm{mg} / 100 \mathrm{~g}$ in $\mathrm{T}_{3}-4.5 \%$ Calcium chloride treated and $10.34 \mathrm{mg} / 100 \mathrm{~g}$ in control fruits at the end of storage, on 32 and 24 days after storage respectively as compared to rest of the treatments. Ascorbic acid is vital nutrient quality parameter and is very sensitive to degradation due to its oxidation (Veltman et al., 2000) paralleled to other nutrients during food processing and storage. The present results showed that $\mathrm{T}_{3}-4.5 \%$ calcium chloride had a significant effect on better retention of ascorbic acid content in Sapota fruit and preventing from its losses during storage. This might be because of higher concentrations of calcium chloride hindered the rapid oxidation of ascorbic acid. Ruoyi et al. also quantified that ascorbic acid content of peaches was preserved at fifty days of storage with a postharvest application of $0.5 \%$ calcium chloride (Ruoyi et al., 2005).

\section{Effect on total tannin content}

The results on pool of tannin content (Table 2) indicated that before storage, initially high tannin content was recorded in both treated $(0.46 \%$ to $0.50 \%)$ and control $(0.41 \%)$ fruits. However, it was declined with storage time. Among the treatments, $\mathrm{T}_{3}-4.5 \%$ calcium chloride recoded $(\mathrm{P}<0.05)$ highest, followed by $\mathrm{T}_{2}-4 \%$ Calcium chloride and $\mathrm{T}_{1}-3 \%$ Calcium chloride as compared to control $(0.41 \%)$. At the end of storage, it was decreased to $0.26 \%$ in control (after 24 days) and to $0.20 \%$ in calcium salt treated ones( $\mathrm{T}_{2}-4 \%$ Calcium chloride and $\mathrm{T}_{1}-3 \%$ Calcium chloride).Tannins are condensed form of phenolics that are very sensitive to degradation due to decline in total organic acids content as indicated by gradual decrease in both titrable acidity and ascorbic acid content in in both treated and control sapota fruits with storage time. Results of storage studies of sapota fruits revealed that the shelf life of fruits treated with $3 \%, 4 \%$ and $4.5 \%$ calcium chloride was extended up to 32 days as compared to control fruits for 24 days.

Effect on pools of total soluble solids ( ${ }^{\circ}$ Brix), and sugars content

The results on total soluble solids content (TSS) revealed that TSS increased gradually in both control and postharvest dip treated fruits during LT storage from $13.33{ }^{\circ} \mathrm{Bx}$ to $20.26^{\circ}$ Brix during 24 Days of LT storage in T0 (control) Sample (Table 2). Among treatments, initially the least TSS was recorded $10.86{ }^{\circ}$ Brix in $\mathrm{T}_{3}-4.5 \%$ calcium chloride and in all calcium chloride pretreated fruits $\left(20.26{ }^{\circ}\right.$ Brix to $\left.20.47^{\circ} \mathrm{Brix}\right)$ on 32nd day of storage. The results on trends of pools of reducing and total sugars indicated 
that there was increase in accumulation of these sugars with storage time, both in control (total sugars from $8.90 \%$ to 17.48 $\%$, reducing sugars from $4.83 \%$ to $13.97 \%$ ) and in treated sapota fruits (total sugars from $6.83 \%$ to $17.19 \%$, reducing sugars from $2.84 \%$ to $13.28 \%$ ) during 24 days and 32 days of storage. Among the treatments, $\mathrm{T}_{3}-$ $4.5 \%$ calcium chloride recoded $(\mathrm{P}<0.05)$ least amount of total sugars to $6.83 \%$ and reducing sugars to $2.84 \%$ and control showed $(\mathrm{P}<0.05)$ highest amount of total sugars to $17.48 \%$ and reducing sugars to $13.97 \%$ at the end of storage.

Results on changes in total soluble solids, total sugars and reducing sugars in the postharvest dip treated Sapota fruits stored at LT condition (Table 2 ) revealed that among the treatments, $\mathrm{T}_{3}-4.5 \%$ calcium chloride recorded $(\mathrm{P}<0.05)$ least $\mathrm{TSS}$, total sugars and reducing sugars during 32 days of LT storage. This could be attributed to the significant delay in the initiation of fruit ripening process by the calcium by inhibition of the metabolic processes such as starch hydrolysis and consequently delay in formation of these sugars that resulted mainly due to high amount of calcium deposition in the fruit cell wall of $\mathrm{T}_{3}-4.5 \%$ calcium chloride treated Sapota fruits. Our results are in confirmatory with those reported earlier (Amarjeet Kumar et al., 2016; Subedi and Bhattari, 1995; Agar and Kaska, 1995).The cell wall constituents such as pectic acid, calcium binding cell wall protein, hemicelluloses and polysaccharides, which are most likely binding sites for calcium (Hanson, 1993). The bound calcium with these pectic compounds preserved the fruit texture and stability of these treated Sapota fruits during 32 days of LT storage. This might have contributed towards the higher fruit confrontation against starch break down by maintaining high calcium concentration in the cytosol and this further might led to the inhibition of respiratory activity in these calcium treated fruit cells (Faust and Shear, 1972) and therefore less free sugars were formed during LT storage. Results of storage studies of sapota fruits revealed that the shelf life of fruits treated with calcium chloride salt with $3 \%, 4 \%$ and $4.5 \%$ was extended the shelf life up to 32 days at $\mathrm{LT}\left(12 \pm 1^{\circ} \mathrm{C}, 90-95 \% \mathrm{RH}\right)$ condition as compared 24 days in control. Both calcium salts treated and control fruits after effective storage life were ripened at RT $\left(29 \pm 2{ }^{\circ} \mathrm{C}, 60-75 \% \mathrm{RH}\right)$ respectively and were used for further studies in the present investigation.

\section{Osmo- dehydrated sapota slices}

\section{Physicochemical characteristics}

Result on changes in the quality attributes and the storage stability of dehydrated sapota slices stored at RT $\left(29 \pm 2^{\circ} \mathrm{C}, 60-75 \%\right.$ $\mathrm{RH}$ ) was evaluated for four months, in terms of hunter color values and texture attributes, TSS, acidity, Total sugar, reducing sugar and ascorbic acid content. Results on initial fruit quality attributes of these products showed that among treatments $\mathrm{T}_{3}-4.5 \%$ Calcium chloride treated sapota slices had $(\mathrm{P}<0.05)$ higher texture as compared to others and control slices. Initially total soluble solids content was $(\mathrm{P}<0.05)$ higher in untreated control as compared to all calcium chloride pretreated sapota slices. It was decreased $(\mathrm{P}<0.05)$ in untreated control and treated sapota slices $\left(4.5 \% \mathrm{CaCl}_{2}\right)$ after four months of RT storage. The titrable acidity decreased in untreated control and sapota fruit slices pretreated with low levels (3\% and $4 \%$ ) of calcium chloride when compared with $4.5 \%$ calcium chloride treatment. However, loss of the ascorbic acid content in all sapota slices pretreated with calcium chloride (3\%, $4 \%$ and $4.5 \%$ ) was $(\mathrm{P}<0.05)$ prevented unlike control 
during 4 months RT storage. Initially control sapota slices showed higher levels of the total sugars, reducing sugar and nonreducing sugars as compared to all treatments. During RT storage for 4 months, proportionate decrease in pools of these sugars was $(\mathrm{P}<0.05)$ higher in control slices than those all treatments.However, the control slices were recorded $(\mathrm{P}<0.05)$ higher TSS, acidity, Total sugar and reducing sugar content as compared to others. It was observed that there was $(\mathrm{P}<0.05)$ decline in texture of sapota slices in control with storage time (after 4 months) as compared to all treated sapota slices.

Table.1 Effect of pretreatments on changes in fruit quality attributes of fresh sapota fruits stored at low temperature $\left(12 \pm 1^{\circ} \mathrm{C}, 90-95 \% \mathrm{RH}\right)$ condition

\begin{tabular}{|c|c|c|c|c|c|}
\hline \multirow[t]{2}{*}{ Day } & \multirow[t]{2}{*}{ Treatment } & \multirow[t]{2}{*}{ Texture } & \multicolumn{3}{|c|}{ Sapota fruits Colour } \\
\hline & & & $\mathbf{L}^{*}$ & $\mathbf{a}^{*}$ & $\mathbf{b}^{*}$ \\
\hline \multirow[t]{4}{*}{0} & $\mathrm{~T}_{0}$ & $88.03 \pm 0.57^{\mathrm{a}}$ & $43.94 \pm 1.04^{\mathrm{a}}$ & $6.26 \pm 0.64^{\mathrm{a}}$ & $20.36 \pm 1.69^{\mathrm{an}}$ \\
\hline & $\mathrm{T}_{1}$ & $87.25 \pm 1.43^{\mathrm{a}}$ & $44.90 \pm 0.83^{\mathrm{a}}$ & $6.93 \pm 0.36^{\mathrm{a}}$ & $19.63 \pm 1.77^{\mathrm{ab}}$ \\
\hline & $\mathrm{T}_{2}$ & $87.75 \pm 0.89^{\mathrm{a}}$ & $43.54 \pm 2.15^{\mathrm{a}}$ & $6.99 \pm 0.61^{\mathrm{a}}$ & $21.14 \pm 1.06^{b}$ \\
\hline & $\mathrm{T}_{3}$ & $87.87 \pm 1.11^{\mathrm{a}}$ & $41.70 \pm 2.91^{\mathrm{a}}$ & $7.19 \pm 0.90^{\mathrm{a}}$ & $17.32 \pm 0.69^{\mathrm{a}}$ \\
\hline \multirow[t]{4}{*}{8} & $\mathrm{~T}_{0}$ & $68.11 \pm 7.36^{\mathrm{a}}$ & $42.94 \pm 1.34^{\mathrm{a}}$ & $5.46 \pm 0.70^{\mathrm{a}}$ & $19.59 \pm 1.82$ \\
\hline & $\mathrm{T}_{1}$ & $84.26 \pm 3.51^{b}$ & $43.35 \pm 0.10^{\mathrm{a}}$ & $6.33 \pm 0.38^{\mathrm{a}}$ & $18.64 \pm 1.38^{\mathrm{a}}$ \\
\hline & $\mathrm{T}_{2}$ & $82.18 \pm 1.62^{b}$ & $42.82 \pm 1.89^{\mathrm{a}}$ & $6.69 \pm 1.14^{\mathrm{a}}$ & $19.64 \pm 0.36^{\mathrm{a}}$ \\
\hline & $\mathrm{T}_{3}$ & $86.64 \pm 1.77^{b}$ & $40.93 \pm 3.06^{\mathrm{a}}$ & $6.72 \pm 1.12^{\mathrm{a}}$ & $16.75 \pm 1.07^{\mathrm{a}}$ \\
\hline \multirow[t]{4}{*}{16} & $\mathrm{~T}_{0}$ & $47.75 \pm 6.06^{\mathrm{a}}$ & $44.92 \pm 2.30^{\mathrm{a}}$ & $5.56 \pm 1.49^{\mathrm{a}}$ & $18.83 \pm 1.90^{\mathrm{a}}$ \\
\hline & $\mathrm{T}_{1}$ & $78.65 \pm 1.52^{b}$ & $43.53 \pm 1.60^{\mathrm{a}}$ & $6.72 \pm 0.41^{\mathrm{a}}$ & $17.99 \pm 1.19^{\mathrm{a}}$ \\
\hline & $\mathrm{T}_{2}$ & $78.31 \pm 3.76^{\mathrm{b}}$ & $45.13 \pm 1.90^{\mathrm{a}}$ & $6.87 \pm 0.93^{\mathrm{a}}$ & $20.12 \pm 1.09^{\mathrm{a}}$ \\
\hline & $\mathrm{T}_{3}$ & $81.88 \pm 4.40^{b}$ & $45.01 \pm 2.00^{\mathrm{a}}$ & $5.92 \pm 0.79^{\mathrm{a}}$ & $20.17 \pm 0.07^{\mathrm{a}}$ \\
\hline \multirow[t]{4}{*}{24} & $\mathrm{~T}_{0}$ & $37.75 \pm 6.06^{\mathrm{a}}$ & $45.32 \pm 1.01^{b}$ & $6.11 \pm 1.00^{\mathrm{a}}$ & $20.43 \pm 0.99^{\mathrm{a}}$ \\
\hline & $\mathrm{T}_{1}$ & $71.96 \pm 3.61^{b}$ & $44.33 \pm 0.56^{\mathrm{ab}}$ & $5.52 \pm 0.93^{\mathrm{a}}$ & $18.48 \pm 1.79^{\mathrm{a}}$ \\
\hline & $\mathrm{T}_{2}$ & $70.29 \pm 3.95^{b}$ & $47.47 \pm 0.76^{\mathrm{c}}$ & $6.44 \pm 0.25^{\mathrm{a}}$ & $20.46 \pm 0.36^{\mathrm{a}}$ \\
\hline & $\mathrm{T}_{3}$ & $72.60 \pm 1.22^{b}$ & $43.01 \pm 1.18^{\mathrm{a}}$ & $5.65 \pm 0.48^{\mathrm{a}}$ & $17.83 \pm 1.14$ \\
\hline \multirow[t]{4}{*}{32} & $\mathrm{~T}_{0}$ & $20.65 \pm 2.69^{\mathrm{a}}$ & $46.05 \pm 1.56^{\mathrm{a}}$ & $6.05 \pm 1.42^{\mathrm{a}}$ & $21.16 \pm 1.57^{\mathrm{ab}}$ \\
\hline & $\mathrm{T}_{1}$ & $63.83 \pm 2.93^{b}$ & $46.20 \pm 0.66^{\mathrm{a}}$ & $6.86 \pm 0.25^{\mathrm{a}}$ & $18.56 \pm 1.04^{\mathrm{a}}$ \\
\hline & $\mathrm{T}_{2}$ & $57.66 \pm 6.36^{b}$ & $46.47 \pm 1.20^{\mathrm{a}}$ & $7.01 \pm 0.72^{\mathrm{a}}$ & $21.46 \pm 0.61^{b}$ \\
\hline & $\mathrm{T}_{3}$ & $62.56 \pm 1.17^{b}$ & $46.67 \pm 1.21^{\mathrm{a}}$ & $6.62 \pm 0.49^{\mathrm{a}}$ & $20.77 \pm 1.40^{\mathrm{ab}}$ \\
\hline
\end{tabular}

Mean scores with different letters differ significantly $(P<0.05)$ by DMRT $\mathrm{T}_{0}$-Control; $\mathrm{T}_{1}-3 \%$ Calcium chloride; $\mathrm{T}_{2}-4 \%$ Calcium chloride; $\mathrm{T}_{3}-4.5 \%$ Calcium chloride 
Int.J.Curr.Res.Aca.Rev.2016; 4(4): 148-165

Table. 2 Effect of pretreatments on changes in fruit compositional attributes of fresh sapota fruits stored at low temperature $\left(12 \pm 1^{\circ} \mathrm{C} ; 90-95 \% \mathrm{RH}\right)$ condition

\begin{tabular}{|c|c|c|c|c|c|c|c|}
\hline Day & Treatment & $\begin{array}{c}\text { Titrable } \\
\text { acidity \% }\end{array}$ & TSS & $\begin{array}{c}\text { Total sugar } \\
\%\end{array}$ & $\begin{array}{l}\text { Reducing } \\
\text { sugar \% }\end{array}$ & $\begin{array}{c}\text { Total } \\
\text { Tannin } \\
\text { mg/100g }\end{array}$ & $\begin{array}{l}\text { Ascorbic } \\
\text { acid } \\
\text { mg/100g }\end{array}$ \\
\hline \multirow[t]{4}{*}{0} & $\mathrm{~T}_{0}$ & $0.70 \pm 0.01^{\mathrm{efg}}$ & $13.33 \pm 0.02^{\mathrm{de}}$ & $8.90 \pm 0.16^{\mathrm{de}}$ & $4.83 \pm 0.77^{\mathrm{d}}$ & $0.41 \pm 0.01^{\text {fgh }}$ & $14.63 \pm 0.62^{\mathrm{f}}$ \\
\hline & $\mathrm{T}_{1}$ & $0.77 \pm 0.01^{\mathrm{g}}$ & $11.74 \pm 0.06^{b}$ & $7.86 \pm 0.16^{\mathrm{bc}}$ & $3.74 \pm 0.12^{\mathrm{bc}}$ & $0.46 \pm 0.01^{\text {ghi }}$ & $15.76 \pm 0.23^{g}$ \\
\hline & $\mathrm{T}_{2}$ & $0.75 \pm 0.01^{\mathrm{g}}$ & $12.18 \pm 0.24^{b c}$ & $7.40 \pm 0.08^{\mathrm{ab}}$ & $3.57 \pm 0.06^{\mathrm{b}}$ & $0.47 \pm 0.01^{\mathrm{hi}}$ & $15.82 \pm 0.19^{g}$ \\
\hline & $\mathrm{T}_{3}$ & $0.74 \pm 0.04^{\mathrm{fg}}$ & $10.86 \pm 0.20^{\mathrm{a}}$ & $6.83 \pm 0.16^{\mathrm{a}}$ & $2.84 \pm 0.20^{\mathrm{a}}$ & $0.50 \pm 0.01^{\mathrm{i}}$ & $16.88 \pm 0.16^{\mathrm{h}}$ \\
\hline \multirow[t]{4}{*}{8} & $\mathrm{~T}_{0}$ & $0.67 \pm 0.02^{\text {ef }}$ & $14.26 \pm 0.36^{\mathrm{g}}$ & $11.93 \pm 0.36^{\mathrm{gh}}$ & $5.76 \pm 0.02^{\mathrm{e}}$ & $0.36 \pm 0.02^{\mathrm{def}}$ & $14.05 \pm 0.08^{\mathrm{ef}}$ \\
\hline & $\mathrm{T}_{1}$ & $0.66 \pm 0.08^{\mathrm{de}}$ & $13.97 \pm 0.04^{\mathrm{fg}}$ & $10.73 \pm 0.16^{\mathrm{f}}$ & $4.44 \pm 0.40^{\mathrm{d}}$ & $0.41 \pm 0.02^{\text {fgh }}$ & $14.32 \pm 0.51^{\mathrm{ef}}$ \\
\hline & $\mathrm{T}_{2}$ & $0.58 \pm 0.02^{\mathrm{c}}$ & $13.55 \pm 0.58^{\mathrm{ef}}$ & $9.29 \pm 0.16^{\mathrm{e}}$ & $4.36 \pm 0.16^{\mathrm{cd}}$ & $0.38 \pm 0.03^{\mathrm{def}}$ & $14.15 \pm 0.16^{\text {ef }}$ \\
\hline & $\mathrm{T}_{3}$ & $0.60 \pm 0.02^{\text {cd }}$ & $12.74 \pm 0.14^{\text {cd }}$ & $8.43 \pm 0.11^{\mathrm{cd}}$ & $4.23 \pm 0.20^{\mathrm{cd}}$ & $0.40 \pm 0.02^{\mathrm{efg}}$ & $14.33 \pm 0.12^{\mathrm{ef}}$ \\
\hline \multirow[t]{4}{*}{16} & $\mathrm{~T}_{0}$ & $0.57 \pm 0.04^{\mathrm{c}}$ & $19.53 \pm 0.57^{j}$ & $14.70 \pm 0.59^{i}$ & $8.16 \pm 0.46^{\mathrm{g}}$ & $0.34 \pm 0.06^{\mathrm{de}}$ & $12.78 \pm 0.65^{d}$ \\
\hline & $\mathrm{T}_{1}$ & $0.54 \pm 0.02^{\mathrm{c}}$ & $16.66 \pm 0.50^{\mathrm{h}}$ & $11.66 \pm 0.63^{g}$ & $6.98 \pm 0.15^{\mathrm{f}}$ & $0.39 \pm 0.04^{\mathrm{efg}}$ & $13.78 \pm 0.37^{\mathrm{e}}$ \\
\hline & $\mathrm{T}_{2}$ & $0.55 \pm 0.08^{\mathrm{c}}$ & $17.40 \pm 0.46^{\mathrm{i}}$ & $12.42 \pm 0.55^{\mathrm{h}}$ & $7.48 \pm 0.58^{f}$ & $0.35 \pm 0.05^{\text {def }}$ & $14.24 \pm 0.70^{\text {ef }}$ \\
\hline & $\mathrm{T}_{3}$ & $0.57 \pm 0.02^{c}$ & $17.03 \pm 0.08^{\mathrm{hi}}$ & $12.06 \pm 0.20^{\mathrm{gh}}$ & $7.18 \pm 0.24^{\mathrm{f}}$ & $0.32 \pm 0.44^{\mathrm{cd}}$ & $13.94 \pm 0.71^{\mathrm{ef}}$ \\
\hline \multirow[t]{4}{*}{24} & $\mathrm{~T}_{0}$ & $0.41 \pm 0.01^{\mathrm{ab}}$ & $20.26 \pm 0.04^{\mathrm{k}}$ & $17.48 \pm 0.16^{1}$ & $13.97 \pm 0.44^{\mathrm{jk}}$ & $0.26 \pm 0.01^{b}$ & $11.28 \pm 0.25^{b}$ \\
\hline & $\mathrm{T}_{1}$ & $0.42 \pm 0.02^{b}$ & $19.61 \pm 0.17^{j}$ & $15.96 \pm 0.22^{i}$ & $12.60 \pm 0.24^{\mathrm{h}}$ & $0.25 \pm 0.03^{b}$ & $12.11 \pm 0.08^{\mathrm{cd}}$ \\
\hline & $\mathrm{T}_{2}$ & $0.42 \pm 0.01^{\mathrm{b}}$ & $19.96 \pm 0.11^{\mathrm{jk}}$ & $16.46 \pm 0.09^{k}$ & $12.78 \pm 0.08^{\text {hi }}$ & $0.21 \pm 0.01^{\mathrm{ab}}$ & $12.27 \pm 0.15^{\mathrm{d}}$ \\
\hline & $\mathrm{T}_{3}$ & $0.42 \pm 0.00^{b}$ & $19.96 \pm 0.08^{\mathrm{jk}}$ & $16.56 \pm 0.16^{\mathrm{k}}$ & $12.72 \pm 0.29^{\mathrm{h}}$ & $0.19 \pm 0.01^{\mathrm{ab}}$ & $12.12 \pm 0.29^{\mathrm{d}}$ \\
\hline \multirow[t]{4}{*}{32} & $\mathrm{~T}_{0}$ & $0.34 \pm 0.01^{\mathrm{a}}$ & $21.60 \pm 0.16^{\top}$ & $18.24 \pm 0.11^{\mathrm{m}}$ & $14.24 \pm 0.06^{\mathrm{k}}$ & $0.18 \pm 0.03^{\mathrm{a}}$ & $10.34 \pm 0.10^{\mathrm{a}}$ \\
\hline & $\mathrm{T}_{1}$ & $0.36 \pm 0.02^{\mathrm{ab}}$ & $20.26 \pm 0.36^{\mathrm{k}}$ & $17.19 \pm 0.22^{\top}$ & $14.04 \pm 0.12^{\mathrm{k}}$ & $0.22 \pm 0.03^{\mathrm{ab}}$ & $11.16 \pm 020^{b}$ \\
\hline & $\mathrm{T}_{2}$ & $0.35 \pm 0.01^{\mathrm{ab}}$ & $20.47 \pm 0.29^{\mathrm{k}}$ & $17.25 \pm 0.14^{1}$ & $13.75 \pm 0.34^{\mathrm{jk}}$ & $0.20 \pm 0.03^{\mathrm{ab}}$ & $11.43 \pm 0.17^{\mathrm{bc}}$ \\
\hline & $\mathrm{T}_{3}$ & $0.35 \pm 0.01^{\mathrm{ab}}$ & $20.36 \pm 0.24^{\mathrm{k}}$ & $17.19 \pm 0.17^{I}$ & $13.28 \pm 0.05^{\mathrm{ij}}$ & $0.20 \pm 0.01^{\mathrm{ab}}$ & $11.34 \pm 0.16^{b}$ \\
\hline
\end{tabular}

Mean scores with different letters differ significantly $(\mathrm{P}<0.05)$ by DMRT $\mathrm{T}_{0}$-Control; $\mathrm{T}_{1}-3 \%$ Calcium chloride; $\mathrm{T}_{2}-4 \%$ Calcium chloride; $\mathrm{T}_{3}-4.5 \%$ Calcium chloride 
Int.J.Curr.Res.Aca.Rev.2016; 4(4): 148-165

Table.3 Physicochemical quality attributes of sapota slices initial and after 4 months of RT $\left(29 \pm 2^{\circ} \mathrm{C} ; 60-75 \% \mathrm{RH}\right)$ Storage

\begin{tabular}{|c|c|c|c|c|c|c|c|c|}
\hline \multirow[b]{2}{*}{ Parameters } & \multicolumn{2}{|c|}{$\mathbf{T}_{0}$} & \multicolumn{2}{|c|}{$\mathbf{T}_{1}$} & \multicolumn{2}{|c|}{$\mathbf{T}_{2}$} & \multicolumn{2}{|c|}{$\mathbf{T}_{3}$} \\
\hline & Initial & $\begin{array}{l}\text { After } 4 \\
\text { months }\end{array}$ & Initial & $\begin{array}{l}\text { After } 4 \\
\text { months }\end{array}$ & Initial & $\begin{array}{l}\text { After } 4 \\
\text { months }\end{array}$ & Initial & $\begin{array}{l}\text { After } 4 \\
\text { months }\end{array}$ \\
\hline $\begin{array}{c}\text { Color values } \\
\text { L* }^{*}\end{array}$ & $\begin{array}{c}37.62 \\
\pm 0.12^{b}\end{array}$ & $\begin{array}{l}38.38 \\
\pm 0.23^{\mathrm{c}}\end{array}$ & $\begin{array}{l}32.02 \\
\pm 2.42^{\mathrm{a}}\end{array}$ & $\begin{array}{c}35.12 \\
\pm 1.75^{\mathrm{b}}\end{array}$ & $\begin{array}{l}32.29 \\
\pm 0.05^{\mathrm{a}}\end{array}$ & $\begin{array}{c}34.14 \\
\pm 0.29^{\mathrm{ab}}\end{array}$ & $\begin{array}{l}30.22 \\
\pm 0.15^{\mathrm{a}}\end{array}$ & $\begin{array}{r}32.42 \\
\pm 0.42^{\mathrm{a}}\end{array}$ \\
\hline$a^{*}$ & $\begin{array}{c}9.20 \\
\pm 0.46^{\mathrm{a}}\end{array}$ & $\begin{array}{c}9.95 \\
\pm 0.69^{\mathrm{a}}\end{array}$ & $\begin{array}{r}10.73 \\
\pm 1.51^{\mathrm{a}}\end{array}$ & $\begin{array}{r}12.25 \\
\pm 0.45^{\mathrm{b}}\end{array}$ & $\begin{array}{c}9.41 \\
\pm 0.21^{\mathrm{a}}\end{array}$ & $\begin{array}{r}10.45 \\
\pm 0.26^{\mathrm{a}}\end{array}$ & $\begin{array}{c}9.01 \\
\pm 0.09^{\mathrm{a}}\end{array}$ & $\begin{array}{c}10.03 \\
\pm 0.12^{\mathrm{a}}\end{array}$ \\
\hline $\mathrm{b}^{*}$ & $\begin{array}{c}16.58 \\
\pm 0.29^{\mathrm{b}}\end{array}$ & $\begin{array}{r}17.33 \\
\pm 0.28^{\mathrm{b}}\end{array}$ & $\begin{array}{r}15.22 \\
\pm 2.29^{\mathrm{ab}}\end{array}$ & $\begin{array}{r}16.28 \\
\pm 1.93^{\mathrm{b}}\end{array}$ & $\begin{array}{r}15.71 \\
\pm 0.33^{\mathrm{b}}\end{array}$ & $\begin{array}{r}16.50 \\
\pm 0.17^{b}\end{array}$ & $\begin{array}{c}12.81 \\
\pm 0.11^{\mathrm{a}}\end{array}$ & $\begin{array}{r}13.78 \\
\pm 0.07^{\mathrm{a}}\end{array}$ \\
\hline $\begin{array}{l}\text { Shear force } \\
\text { (N) }\end{array}$ & $\begin{array}{c}133.6 \\
\pm 19.77^{\mathrm{a}}\end{array}$ & $\begin{array}{l}157.53 \\
\pm 12.5^{\mathrm{a}}\end{array}$ & $\begin{array}{r}140.55 \\
\pm 4.66^{\mathrm{ab}}\end{array}$ & $\begin{array}{l}173.85 \\
\pm 4.45^{\mathrm{b}}\end{array}$ & $\begin{array}{l}162.96 \\
\pm 9.87^{\mathrm{b}}\end{array}$ & $\begin{array}{l}170.36 \\
\pm 9.08^{\mathrm{b}}\end{array}$ & $\begin{array}{l}155.90 \\
\pm 2.10^{\mathrm{ab}}\end{array}$ & $\begin{array}{l}172.40 \\
\pm 2.90^{\mathrm{b}}\end{array}$ \\
\hline TSS $\left({ }^{0}\right.$ Brix $)$ & $\begin{array}{c}30.06 \\
\pm 0.87^{\mathrm{b}}\end{array}$ & $\begin{array}{l}28.20 \\
\pm 0.35^{\mathrm{c}}\end{array}$ & $\begin{array}{c}26.24 \\
\pm 0.39^{\mathrm{a}}\end{array}$ & $\begin{array}{c}24.7 \\
\pm 0.32^{\mathrm{b}}\end{array}$ & $\begin{array}{l}25.72 \\
\pm 1.24^{\mathrm{a}}\end{array}$ & $\begin{array}{r}24.35 \\
\pm 0.50^{\mathrm{b}}\end{array}$ & $\begin{array}{l}25.71 \\
\pm 0.53^{\mathrm{a}}\end{array}$ & $\begin{array}{c}23.1 \\
\pm 0.24^{\mathrm{a}}\end{array}$ \\
\hline Acidity (\%) & $\begin{array}{c}0.40 \\
\pm 0.01^{\mathrm{b}}\end{array}$ & $\begin{array}{c}0.32 \\
\pm 0.01^{\mathrm{b}}\end{array}$ & $\begin{array}{c}0.32 \\
\pm 0.01^{\mathrm{a}}\end{array}$ & $\begin{array}{c}0.30 \\
\pm 0.01^{\mathrm{ab}}\end{array}$ & $\begin{array}{c}0.30 \\
\pm 0.01^{\mathrm{a}}\end{array}$ & $\begin{array}{c}0.28 \\
\pm 0.01^{\mathrm{a}}\end{array}$ & $\begin{array}{c}0.307 \\
\pm 0.00^{\mathrm{a}}\end{array}$ & $\begin{array}{c}0.32 \\
\pm 0.01^{b}\end{array}$ \\
\hline $\begin{array}{l}\text { Total sugars } \\
(\%)\end{array}$ & $\begin{array}{c}24.55 \\
\pm 0.50^{\mathrm{b}}\end{array}$ & $\begin{array}{c}18.7 \\
\pm 0.32^{b}\end{array}$ & $\begin{array}{r}18.40 \\
\pm 0.56^{\mathrm{a}}\end{array}$ & $\begin{array}{c}16.3 \\
\pm 0.40^{\mathrm{a}}\end{array}$ & $\begin{array}{c}18.1 \\
\pm 0.50^{\mathrm{a}}\end{array}$ & $\begin{array}{r}16.16 \\
\pm 0.20^{\mathrm{a}}\end{array}$ & $\begin{array}{c}17.64 \\
\pm 0.29^{\mathrm{a}}\end{array}$ & $\begin{array}{c}15.5 \\
\pm 0.66^{\mathrm{a}}\end{array}$ \\
\hline $\begin{array}{l}\text { Reducing } \\
\text { Sugar (\%) }\end{array}$ & $\begin{array}{c}14.8 \\
\pm 0.77^{\mathrm{c}}\end{array}$ & $\begin{array}{c}13.29 \\
\pm 0.55^{\mathrm{b}}\end{array}$ & $\begin{array}{c}11.82 \\
\pm 0.19^{\mathrm{b}}\end{array}$ & $\begin{array}{c}9.86 \\
\pm 0.41^{\mathrm{a}}\end{array}$ & $\begin{array}{c}10.38 \\
\pm 0.35^{\mathrm{a}}\end{array}$ & $\begin{array}{c}9.83 \\
\pm 0.38^{\mathrm{a}}\end{array}$ & $\begin{array}{c}10.24 \\
\pm 0.35^{\mathrm{a}}\end{array}$ & $\begin{array}{c}9.3 \\
\pm 0.42^{\mathrm{a}}\end{array}$ \\
\hline $\begin{array}{l}\text { Ascorbic } \\
\text { Acid (mg } \\
/ 100 g)\end{array}$ & $\begin{array}{c}10.4 \\
\pm 1.07^{\mathrm{a}}\end{array}$ & $\begin{array}{c}8.93 \\
\pm 0.53^{\mathrm{a}}\end{array}$ & $\begin{array}{c}11.2 \\
\pm 0.35^{\mathrm{a}}\end{array}$ & $\begin{array}{c}10.2 \\
\pm 0.65^{\mathrm{b}}\end{array}$ & $\begin{array}{c}11.44 \\
\pm 0.45^{\mathrm{a}}\end{array}$ & $\begin{array}{c}10.56 \\
\pm 0.20^{\mathrm{b}}\end{array}$ & $\begin{array}{c}11.25 \\
\pm 0.21^{\mathrm{a}}\end{array}$ & $\begin{array}{r}10.66 \\
\pm 0.61^{b}\end{array}$ \\
\hline
\end{tabular}

The mean differences of the physicochemical quality attributes of sapota slices in row by DMRT at significance $\mathrm{P} \leq 0.05$ level; $\mathrm{T}_{0}-$ Control; $\mathrm{T}_{1}-3 \%$ Calcium chloride; $\mathrm{T}_{2}-4 \%$ Calcium chloride; $\mathrm{T}_{3}-$ $4.5 \%$ Calcium chloride 
Table. 4 Humidity moisture content data of sapota slices $\left(\mathrm{T}_{0}\right.$-Control; $\mathrm{T}_{2}-4 \%$ Calcium chloride;

$\mathrm{T}_{3}-4.5 \%$ Calcium chloride) at $27^{\circ} \mathrm{C}$

\begin{tabular}{|c|c|c|c|c|c|}
\hline \multirow{2}{*}{ S1. No. } & \multirow{2}{*}{$\mathrm{RH}(\%)$} & \multicolumn{3}{|c|}{ EMC Dry wt. \% } & \multirow{2}{*}{ Remarks } \\
\hline & & $\mathrm{T}_{0}$ & $\mathrm{~T}_{2}$ & $\mathrm{~T}_{3}$ & \\
\hline 1 & 11 & 6.89 & 5.54 & 5.34 & Good, more crispy \\
\hline 2 & 22 & 6.92 & 7.39 & 5.99 & Little hard \\
\hline 3 & 32 & 7.58 & 7.77 & 6.22 & More hard \\
\hline 4 & 44 & 10.17 & 9.76 & 8.65 & Hard \\
\hline 5 & 56 & 14.28 & 14.54 & 14.02 & Soft ,good taste \\
\hline 6 & 64 & 19.44 & 19.61 & 18.43 & Darken, color change \\
\hline 7 & 75 & 28.25 & 28.44 & 26.33 & Slightly darken \\
\hline 8 & 86 & 39.93 & 39.92 & 38.16 & Mold In 4 Week \\
\hline 9 & 92 & 54.56 & 57.07 & 57.68 & Mold In 3 Week \\
\hline Initial Moisture Content (IMC \%) & \multicolumn{2}{|c|}{16.85} & 13.78 & 12.99 & \\
\hline Critical Moisture Content (CMC \%) & \multicolumn{2}{|c|}{20.13} & 16.91 & 16.04 & \\
\hline Equilibrium Relative Humidity (ERH \%) & \multicolumn{2}{|c|}{65} & 58 & 58 & \\
\hline Critical Relative Humidity (CRH \%) & \multicolumn{2}{|c|}{70} & \multicolumn{2}{|c|}{64} & \\
\hline
\end{tabular}

Figure.1 Flow chart on preparation of dehydrated sapota slices

\section{Harvesting of optimally matured fruit}<smiles>[CH]1C=C1</smiles>

Pre-treatments with aqueous solutions of calcium chloride salts for 15 minutes

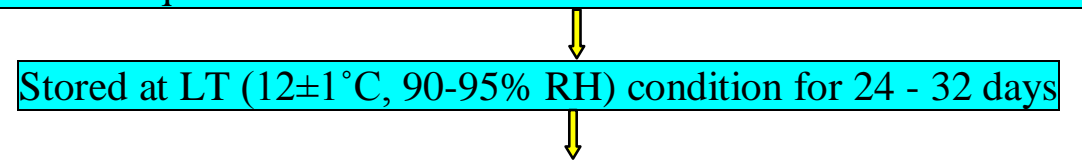

LT stored fruits were fully ripened, Sorted, graded for uniform size and color<smiles>[CH]1C=C1</smiles>

Complete ripe sapota fruits were water washed<smiles>C1=CC=C1</smiles>

Slicing into uniform size $(8-10 \mathrm{~mm}) \&$ dipping into $0.05 \%$ sodium hypochlorite solution

$50 \%$ sugar syrup containing $0.25 \%$ Citric acid and $0.1 \%$ KMS (slices to syrup ratio, $1: 1$ )

$\sqrt{ }$

Sapota slices were dipped in sugar syrup for 2 hours at RT $\left(29 \pm 2^{0} \mathrm{C}\right)$

$\|$

Dipped slices were kept in hot air drier at $60^{\circ} \mathrm{C}$ for till $11-15 \%$ moisture content $\|$

Dehydrated slices were packed in LDPE polythene bag

Storage stability studies of sapota slices at RT $\left(29 \pm 2^{0} \mathrm{C}\right)$ 
Figure. 2 Moisture sorption isotherm of sapota slices (T0-Control; $\mathrm{T}_{2}-4 \%$ Calcium chloride; $\mathrm{T}_{3}-4.5 \%$ Calcium chloride) at $27^{\circ} \mathrm{C}$.

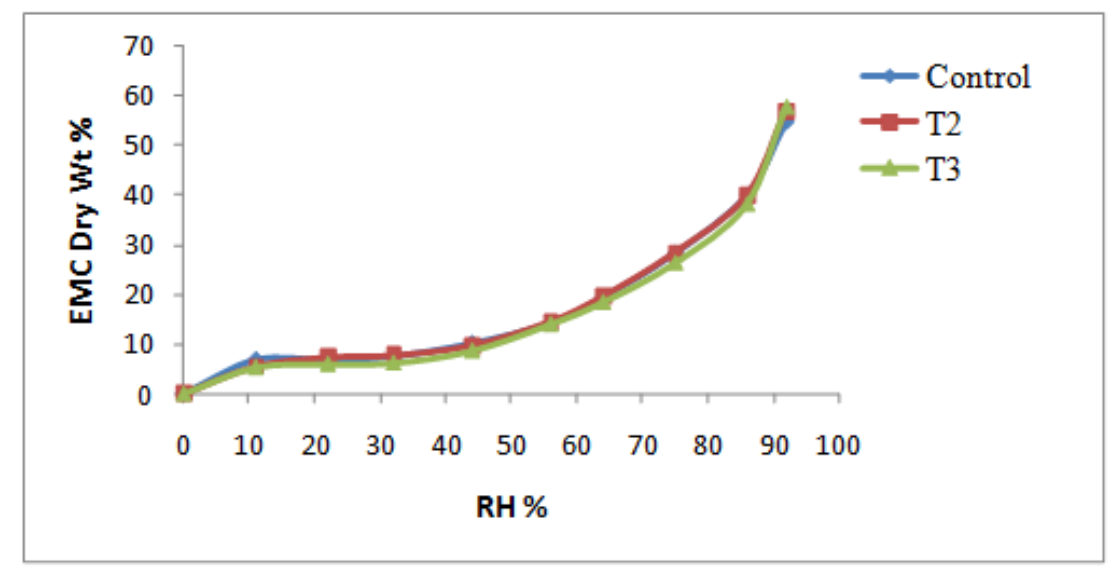

Figure.3 Sensory profile of dehydrated sapota slices initial before storage at RT $\left(29 \pm 2^{\circ} \mathrm{C}, 60\right.$ $75 \% \mathrm{RH}$ ) storage. $\mathrm{T}_{0}$-Control; $\mathrm{T}_{1}-3 \%$ Calcium chloride; $\mathrm{T}_{2}-4 \%$ Calcium chloride; $\mathrm{T}_{3}-4.5 \%$ Calcium chloride

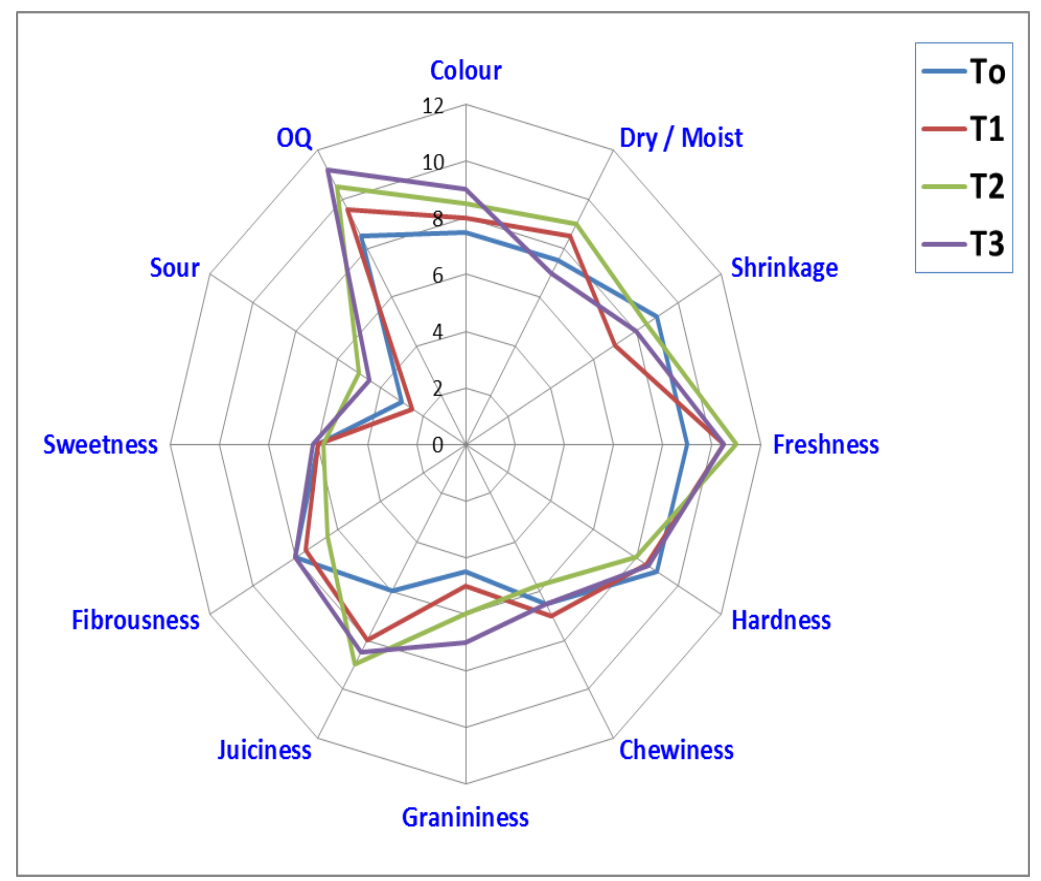

The sapota slices of all treatments $\left(\mathrm{T}_{1}-3 \%\right.$ Calcium chloride; $\mathrm{T}_{2}-4 \%$ Calcium chloride; $\mathrm{T}_{3}-4.5 \%$ Calcium chloride) had retained $(\mathrm{P}<0.05)$ higher texture at the end of 4 months of RT storage. In calcium salts pretreated sapota fruits that osmo- dehydrated sapota slices showed higher resistance against greater stress and strain at failure values than the fresh sapota fruits and this behaviour was enhanced by calcium addition, resulting in an increase in hardness and resistance to deformation in relation to 
fresh sapota fruits. The firming effect provided by calcium salts could be explained by the linkage of calcium ions with cell wall and middle lamella pectin, promoting the structural preservation of these pre-treated sapota fruits.

While results on changes in the pools of TSS, acidity, Total sugar, reducing sugar and ascorbic acid content during 4 months of RT storage indicated that all the treatments were recorded proportionately less than control slices exceptionally all these treatments were retained $(\mathrm{P}<0.05)$ higher ascorbic acid content as compared to the control slices. Further, the quality of the product in untreated control after 4 months (Data not presented) was deteriorated in terms of off flavor development, gradual decrease in texture of slices, decrease in the pools of the chemical quality parameters total sugar, reducing sugars, titrable acidity and ascorbic acid content. These results showed that the both the product quality and the shelf stability of the products prepared from $\mathrm{T}_{1}-3 \%$ Calcium chloride; $\mathrm{T}_{2}-4 \%$ Calcium chloride; $\mathrm{T}_{3}-4.5 \% \quad$ Calcium chloride, LT stored sapota fruits can be achieved up to four months at RT $\left(25-28^{\circ} \mathrm{C}\right.$, $60-75 \% \mathrm{RH})$ storage.

\section{Moisture sorption studies}

In order to design functional economic package for three variants sapota slices (T0Control; $\mathrm{T}_{2}-4 \%$ Calcium chloride; $\mathrm{T}_{3}-4.5 \%$ Calcium chloride) which are nonhygroscopic, their moisture sorption characteristics were studied. The moisture sorption isotherms are presented in Figure 2. As can be seen in fig the moisture sorption isotherm of three formulations is almost similar and sigmoid indicating the typical of a low fat fiber rich products. The curves start raising high above $56 \% \mathrm{RH}$ indicating the products deteriorates faster above $56 \%$
RH. The products T0-Control; $\mathrm{T}_{2}-4 \%$ Calcium chloride; $\mathrm{T}_{3}-4.5 \%$ Calcium chloride with an Initial moisture content of 16.85 to $12.99 \%$ on as is basis equilibrates to 65 and $58 \%$ RH respectively. The products equilibrating up to $22 \% \mathrm{RH}$ in the moisture range of 5.76 to $5.22 \%$ was little hard. Three products T0-Control; $\mathrm{T}_{2}-4 \%$ Calcium chloride; $\mathrm{T}_{3}-4.5 \%$ Calcium chloride equilibrated to $32 \%$ with moisture contents of $6.31 \%$ to 5.42 respectively, $\mathrm{T}_{2}-4 \%$ Calcium chloride; $\mathrm{T}_{3}-4.5 \%$ Calcium chloride had a tendency for soft and slightly better compared to T0-Control, product which is hard. The products T0-Control; $\mathrm{T}_{2}-4 \%$ Calcium chloride; $\mathrm{T}_{3}-4.5 \%$ Calcium chloride equilibrated to $44 \% \mathrm{RH}$ with a moisture content of 8.46 and $7.53 \%$ respectively, The product T0-Control is hard whereas $\mathrm{T}_{2}-4 \%$ Calcium chloride; $\mathrm{T}_{3}-4.5 \%$ Calcium chloride are soft and good in taste and at higher $\mathrm{RH}$ they became soft, darken, colour changes and developed mould growth at 92 and $86 \%$ $\mathrm{RH}$ in 3 and 4 weeks' time.

Hence the moisture content equilibrating to $70 \% \mathrm{RH}$ for T0-Control and 64\% $\mathrm{RH}$ for $\mathrm{T}_{2-}$ $4 \%$ Calcium chloride; $\mathrm{T}_{3}-4.5 \%$ Calcium chloride respectively was taken as critical for three sapota slices variants. The moisture tolerance of T0-Control; $\mathrm{T}_{2}-4 \%$ Calcium chloride; $\mathrm{T}_{3}-4.5 \%$ Calcium chloride are $20.13-16.85=3.28 \%, \quad 16.91-13.78=3.13 \%$ and $16.04-12.99=3.05 \%$ (The difference between initial and critical moisture contents) respectively. The products T0Control; $\mathrm{T}_{2}-4 \%$ Calcium chloride; $\mathrm{T}_{3}-4.5 \%$ Calcium chloride having the moisture tolerance of almost same with minimal difference. From the mathematical calculations (Rangana, 1997) the permeability limit for water vapour transmission rate (WVTR) of packaging material required for storage of sapota slices variants should be less than $150 \times 10-8$ $\mathrm{cc} / \mathrm{cm} 2 / \mathrm{sec} / \mathrm{cm}$ of $\mathrm{Hg}$ at $25^{\circ} \mathrm{C}$. Hence, 
packaging materials like $75 \mu \mathrm{m}$ LDPE; 50 $\mu \mathrm{m}$ cast $\mathrm{PP}, 25 \mu \mathrm{m}$ HDPE are suitable for the required shelf life of 300 days.

\section{Sensory Profile studies}

The initial sensory profile analysis of sapota slices before RT storage is given in Figure 3. Results showed that product prepared from fruits pretreated with $\mathrm{T}_{3}-4.5 \%$ Calcium chloride had highest sensory scores for attributes such as retention of the product colour, freshness, hardeness, grainess, juiciness, sweetness and overall quality attributes as compared to untreated control, followed by $\mathrm{T}_{2}-4 \%$ Calcium chloride and $\mathrm{T}_{1}-3 \%$ Calcium chloride. All the above product samples were acceptable with shelf life of four months. However, data on sensory profile analysis of sapota slices after 4 months of RT storage has not been reported. Results on sensory profile data of the product revealed that among the treatments the overall acceptability of $\mathrm{T}_{3}$ 4.5\% Calcium chloride was found higher, followed by $\mathrm{T}_{2}-4 \%$ Calcium chloride and $\mathrm{T}_{1}-3 \%$ Calcium chloride as compared untreated control product sample. Sensory analysis showed that the use of Calcium chloride salt as fruit hardening chemical agent had improved the textural characteristic of the sapota slices during subsequent RT storage. Similar observations on sapota marmalade prepared from sapota fruits pretreated with Calcium chloride salt as fruit hardening chemical agent were reported by Amarjeet Kumar et al., 2016. Saftner et al. also found that sensory evaluations of the samples treated with calcium propionate and calcium chelate $(40 \mathrm{mM})$ were taste free and did not impart a lip feel (Saftner et al., 2003), while MartinDiana et al. did not find significant differences in sensory attributes (browning, texture or off-flavors) between samples treated with calcium lactate and calcium chloride (Martin-Diana et al., 2005).

\section{Conclusion}

It may be concluded from the present investigation that among the treatments, optimally matured sapota fruits pretreated with $\mathrm{T}_{2}-4 \%$ Calcium chloride and $\mathrm{T}_{3}-4.5 \%$ Calcium chloride treatments stored at LT $\left(12 \pm 1^{\circ} \mathrm{C}, 90-95 \% \mathrm{RH}\right)$ condition were most effective surface hardening chemical agents, with better retention of the fruit quality attributes, without fruit spoilage, with effective shelf life of 32 days as compared 24 days in untreated control sapota fruits stored at same storage condition. Both the Initial and final dehydrated sapota slices products prepared from $\mathrm{T}_{2}-4 \%$ Calcium chloride and $\mathrm{T}_{3}-4.5 \%$ Calcium chloride pretreated, LT stored sapota fruits were found to be excellent in terms all the product quality parameters evaluated with the shelf stability of 4 months at RT $\left(29 \pm 2^{\circ} \mathrm{C}, 60\right.$ $75 \% \mathrm{RH})$ condition. Moisture sorption studies revealed that $75 \mu \mathrm{m}$ LDPE; $50 \mu$ mcast PP or $25 \mu$ HDPE are the most suitable packaging material for dehydrated sapota slices. The dehydrated sapota slices developed in this study represents an innovative and natural processed product from $4 \%$ Calcium chloride and $4.5 \%$ Calcium chloride pretreated and LT stored sapota fruits, which can be incorporated into different food products due to its high nutritional and sensory quality attributes.

\section{Acknowledgement}

Authors are thankful to Director, CSIRCFTRI, Mysore for his constant encouragement and also Mr. Lokesh and Mr. Harish, Technical Officers, CIFS Department for their technical help rendered towards color and texture measuring systems. 


\section{References}

AACC, 1983. Approved methods of Cereal Chemists, $8^{\text {th }}$ Edm, Vol.1, Minnesota, USA.

Abadio, F.D.B., Domingues, A.M., Borges, S.V., DE Oliveira, V.M. 2004. Physical properties of powdered pineapple (Ananascomosus) juiceeffect of maltodextrin concentration and atomization speed. J. Food Engineering, 64: 285-287.

Agar L, Kaska, M. 1995. Effect of different harvest dates and post-harvest treatments on the storage quality of Mandarins. In: Proceedings of the International Symposium on PostHarvest Physiology, Pathology and Technologies for Horticultural Commodities: Recent Advances. 1621 Jan'1994, Agadir, Morocco, pp.7582.

Ahmed, T. et al. 2011. Preparation of Jam from Sapota (Achras zapota). A Scientific J. Krishi Foundation and the Agriculturists, 9(1\&2): 1-7 (2011) ISSN-1729-5211.

Alzamora, S.M., Salvatori, D., Tapia, M.S., Lopez-Malo, A., Weltichanes, J., Fito, P. 2005. Novel functional foods from vegetable matrices impregnated with biologically active compounds. $J$. Food Engineering, 67: 205-214.

Amarjeet, K., Chauhan, A.S., Ravi, R., Kudachikar, V.B. 2016. Influence of pretreatments and storage condition on the quality of Sapota (Achras zapota) fruit and on its processed product marmalade. Int. J. Curr. Sci., 19(1): E133-145.

AOAC Official Method. 1990. Official Methods of Analysis. $15^{\text {th }}$ edn. Association of Official Analytical Chemists, Virgenia, USA.

Brant, L.A. 2002. Calcium the essential mineral. Formulation and Ingredient
Challenges, Issue November.

Available from www.prepared foods.com/archives/2002.

Cano-Chauca, M., Stringheta, P.C., Ramos, A.M., Cal-Vidal, J. 2005. Effect of the carriers on the microstructure of mango powder obtained by spray drying and its functional characterization. Innovative Food Sci. Emerg. Technol., 4(6): 420-428.

Chopda, C.A., Barrett, D.M. 2001. Optimization of guava juice and powder production. J. Food Processing and Preservation, 25(6): 411-430.

Chardonnet, C.O., Charron, C.S., Sams, C.E., Conway, W.S. 2003. Chemical changes in the cortical tissue and cell walls of calcium infiltrated 'Golden Delicious' apples during storage. Postharvest Biol. Technol., 28: 97111.

Conway, W.S., Sams C.E., Watada, A.E. 1997. Relationship between total and cell wall bound calcium in apples following postharvest pressure infiltration of calcium chloride. Acta Horticulturae, 398: 31-39.

Dimitrios, G., Pavlina, D.D. 2005. Summerpruning and pre-harvest calcium chloride sprays affect storability and low temperature breakdown incidence in kiwifruit. Postharvest Biol. Technol., 36: 303-308.

Ding, C.K., Chachin, Y., Hamauzu, Y., Ueda., Imahori, Y. 1998. Effects of storage temperatures on physiology and quality of loquat fruit. Postharvest Biol. Technol., 14(3): 309-315.

DE Oliveira, M.A., DE Maia, G.A., DE Figueiredo, R.W., DE Souza, A.C.R., DE Brito, E.S., DE Azeredo, H.M.C. 2009. Addition of cashew tree gum to maltodextrin based carriers for spray 
drying of cashew apple juice. Int. J. Food Sci. Technol., 44: 641-645.

Ganjyal, G.M., Hanna, M.A., Devadattam, D.S.K. 2003. Processing of zapota (sapodilla): Drying. J. Food Sci., 68: 517-520.

Garcia, E., Barrett, D.M. 2002. Preservative treatments for fresh-cut fruits and vegetables. In: Lamikanra, O. (Ed). Fresh-cut fruits and vegetables: Science, technology and market. Boca Raton, Fla: CRC Press. pp 267-303.

Hanson, E.J, Beggs, J.L., Beaudry, R.M. 1993. Applying calcium chloride postharvest to improve high bush blueberry firmness. Hort Sci., 28(10): 1033-1034.

Hunter, S. 1975. The measurement of appearance. John Wiley and Sons.New York, 304-305.

Kadir, S.A. 2004. Fruit quality at harvest of Jonathan' apple treated with foliarly applied calcium chloride. J. Plant Nutrition, 27: 1991-2006.

Lamikanra, O., Watson, M.A. 2004. Storage effect on lipase activity in fresh-cut cantaloupe melon. J. Food Sci., 69: 126-30.

Lara, I., García, P., Vendrell, M. 2004. Modifications in cell wall composition after cold storage of calcium-treated strawberry (Fragaria $\times a n a n a s s a$ Duch.) fruit. Postharvest Biol. Technol., 34: 331339.

Lopeza, A., Piquem, M.T., Clop, M., Tasias, J., Romero, A., Boatella, J., Garcia, J. 1995. The hygroscopic behavior of the hazelnut. J. Food Engineering, 25(2): 197-208.

Luna-Guzman, I., Barrett, D.M. 2000. Comparison of calcium chloride and calcium lactate effectiveness in maintaining shelf stability and quality of fresh-cut cantaloupes. Postharvest Biol. Technol., 19: 61-72.
Manganaris, G.A., Vasilakakis, M., Diamantidis, G., Mignani, I. 2007. The effect of postharvest calcium application on tissue calcium concentration, quality attributes, incidence of flesh browning and cell wall physicochemical aspects of peach fruits. Food Chem., 4: 13851392.

Martin-Diana, A.B., Rico, D., Barry-Ryan, C., Frias, J.M., Mulcahy, J., Henehan, G.T.M. 2005. Comparison of calcium lactate with chlorine as washing treatment for fresh-cut lettuce and carrots: quality and nutritional parameters. J. Sci. Food Agri., 85: 2260-2268.

Ranganna, S. 1999. Hand book of Analysis and Quality control for fruits and vegetable products. $3^{\text {rd }}(\mathrm{Edn})$. Tata McGraw Hill publishing co. ltd, New Delhi.

Ranganna, S. 1997. Handbook of Analysis of Quality Control for Fruit and Vegetable Products. $2^{\text {nd }}($ Edn). Tata McGraw Hill Publishing Company Limited, New Delhi.

Ruoyi, K., Zhifang, Y., Zhaoxin, L.Z. 2005. Effect of coating and intermittent warming on enzymes, soluble pectin substances and ascorbic acid of Prunus persica (cv.Zhonghuashoutao) during refrigerated storage. Food Res. Int., 38: 331-336.

Saftner, R.A., Bai, J., Abbott, J.A., Lee, Y.S. 2003. Sanitary dips with calcium propionate, calcium chloride or calcium amino acid chelate maintain quality and shelf stability of fresh-cut honey dew chunks. Postharvest Biol. Technol., 29: 257-269.

SAS Institute, 1989. Users Guide, Statistic Version 8.02 SAS Institute, Inc. Carey, NC USA.

Sauri-Duch, E., Centurión-Yah, A.R., Vargas-Vargas, L. 2010. Alternative 
tropical fruits in order to increment the offer to European market. Acta. Horticulture, 864: 305-316.

Serrano, M., Martínez-Romero, D., Castillo, S., Guillen, F., Valero, D. 2004. Effect of preharvest sprays containing calcium, magnesium and titanium on the quality of peaches and nectarines at harvest and during postharvest storage. J. Sci., Food and Agri., 84: 1270-1276.

Stone, H., Sidel, J.L., Oliver, S., Woolsey, A., Singleton, R.C. 1974. Sensory evaluation by quantitative descriptive analysis. Food Technol., 28: 24-34.

Subedi, P.P., Bhattarai, S.P. 1995. The effects of low cost cellar structure upon the storage of mandarin fruits in the sub tropics. In: Proceedings of the International Symposium on PostHarvest Physiology, Pathology and Technologies for Horticultural Commodities: Recent Advances. 1621 Jan (1994). Agadir, Morocco. pp. 137-146.

Tonon, R.V.C., Baret., Hubinger, M.D. 2008. Influence of process conditions on the physicochemical properties of acai (Euterpe oleraceae Mart.) powder produced by spray drying. $J$. Food Engineering, 88: 411-418.

Tonon, R.V., Baroni, A.F., Baret, C., Gibert, O., Palet, D., Hubinger, M.D. 2009. Water sorption and glass transition temperature of spray dried acai (Euterpe oleracea Mart.) juice. J. Food Engineering, 94: 215-221.

Veltman, R.H., Kho, R.M., Van Schaik, A.C.R., Sanders, M.G., Oosterhaven, J. 2000. Ascorbic acid and tissue browning in pears (Pyrus communis L., cvs Rocha and Conference) under controlled atmosphere conditions. Postharvest Biol. Technol., 19: 129137.

White, P.J., Broadley, M.R. 2003. Calcium in plants. Ann. Bot., 92(4): 487-511.

Youssefi, S.H., Emam-djomeh, Z., Mousavi, S.M. 2009. Comparison of artificial neural network (ANN) and response surface methodology (RSM) in the prediction of quality parameters of spray-dried pomegranate juice. Drying Technol., 27: 910-917.

\section{How to cite this article:}

Amarjeet, K., A. S. Chauhan, K. Srinivasulu, R. Ravi, and Kudachikar, V. B. 2016. Effect of Pretreatments and Storage Conditions on Shelf life Extension of Sapota (Achras zapota) Fruit and on Quality of Osmo-Dehydrated Slices. Int.J.Curr.Res.Aca.Rev.4(4): 148-165.

doi: http://dx.doi.org/10.20546/ijcrar.2016.404.019 